University of Michigan Law School

University of Michigan Law School Scholarship Repository

Articles

Faculty Scholarship

2006

\title{
The Report of the President's Advisory Panel on Federal Tax Reform: A Critical Assessment and a Proposal
}

Reuven S. Avi-Yonah

University of Michigan Law School, aviyonah@umich.edu

Available at: https://repository.law.umich.edu/articles/41

Follow this and additional works at: https://repository.law.umich.edu/articles

Part of the Taxation-Federal Commons, and the Tax Law Commons

\section{Recommended Citation}

Avi-Yonah, Reuven S. "The Report of the President's Advisory Panel on Federal Tax Reform: A Critical Assessment and a Proposal." SMU L. Rev. 59, no. 2 (2006): 551-87.

This Article is brought to you for free and open access by the Faculty Scholarship at University of Michigan Law School Scholarship Repository. It has been accepted for inclusion in Articles by an authorized administrator of University of Michigan Law School Scholarship Repository. For more information, please contact mlaw.repository@umich.edu. 


\title{
The Report of the President's Advisory Panel on Federal Tax Reform: A Critical Assessment ANd A Proposal
}

\author{
Reuven S. Avi-Yonah*
}

\section{INTRODUCTION}

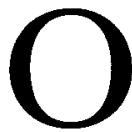

N November 1, 2005, The President's Advisory Panel on Federal Tax Reform ("Panel") submitted its report ("Report") to the Secretary of the Treasury. ${ }^{1}$ At 272 pages, this is the most important and wide-ranging plan to reform the United States federal tax system since Blueprints for Basic Tax Reform (1977). ${ }^{2}$ While prospects for immediate action appear dim, the Report will no doubt be the basis of discussion of federal tax reform for a long time to come.

This article attempts a preliminary evaluation of the Report. It first tries to situate the Report in the context of the long-lasting debate about whether income or consumption should be the proper tax base, and to explain why neither of the two plans endorsed by the Panel (the Simplified Income Tax ("SIT") Plan and the Growth and Investment Tax ("GIT") Plan) completely abandons income taxation. Second, the article evaluates each of the SIT and GIT Plans and points out some problem areas in each proposal. Finally, the article advances an alternative proposal that abandons the political constraint imposed by President Bush (revenue neutrality) and calls for parts of both the SIT and GIT Plans to be enacted.

\section{THE INCOME VERSUS CONSUMPTION TAX DEBATE}

To understand the Report, it is necessary to place it in the context of the thirty year-long debate about whether the United States should tax income or consumption at the federal level. This requires an understanding of the issues surrounding the income versus consumption tax debate.

* Irwin I. Cohn Professor of Law, and Director, International Tax LLM Program, the University of Michigan. This article is dedicated to the memory of the late David Bradford, a scholar and a gentleman.

1. The President's Advisory Panel on Federal Tax Reform, Simple, Fair and Pro-Growth: Proposals to Fix America's Tax System (2005) [hereinafter REPORT).

2. Dep't of the Treasury, Blueprints for Basic Tax Reform (1977) [hereinafter BLUEPRINTS]. 
The following discussion is reprinted from Tax Notes. ${ }^{3}$

The United States individual income tax was enacted in 1913 to replace existing consumption taxes (tariffs) on the ground that they were regressive. Until World War II, it was imposed mainly on upper-income taxpayers and was imposed at low rates, compared with the current individual income tax rates. Even after the War, with rates soaring to [ninety-one] percent, the income tax enjoyed considerable popularity as the fairest tax. However, beginning with California's tax revolt in the early 1970s, an increasing barrage of criticism has been leveled at the income tax on grounds of inefficiency and complexity. At the same time, perceptions of the income tax's fairness have been undermined by the increasing use of sophisticated tax shelters by the rich to reduce or eliminate their income tax liability. While the Tax Reform Act of 1986 achieved considerable simplification of the income tax by reducing its rates and expanding its base, subsequent enactments (especially in the late 1990s) have eroded the gains of the 1986 act and have once again prepared the ground for the advocates of radical tax reform to press for replacing the income tax with a consumption tax.

In the legal academic literature, the recent debate on the appropriate tax base began with Prof[essor] William Andrews's seminal 1974 article in the Harvard Law Review, published just as the decline of the income tax was beginning. ${ }^{4}$ Before Andrews, legal tax scholars assumed that a consumption tax had to be regressive because it is based on sales and therefore cannot take into account the personal characteristics of the buyer. Andrews, building on earlier economics literature (for example, by Nicholas Kaldor), showed that in principle it is possible to achieve a consumption tax with a progressive rate structure built in. He did this by showing that on the basis of certain assumptions (to be explored below), allowing taxpayers to deduct all of their savings and applying graduated rates to them when they consume those savings is equivalent to not taxing the income from those savings at all. Thus, under the Haig-Simons definition of income as consumption plus the increase in savings, exempting the income from savings is equivalent to only taxing consumption.

Prof[essor] Alvin Warren replied to Andrews by arguing that a cash flow consumption tax, as proposed by Andrews, is equivalent to an exemption of the returns on savings, and therefore only labor income will be taxed, which he considered unfair. ${ }^{5}$ Prof[essor] Barbara Fried added that the supposed unfairness of taxing income "twice" (once when earned and again when it produces interest) is illusory,

3. Reprinted with permission. Reuven S. Avi-Yonah, Risks, Rents, and Regressivity: Why the United States Needs Both an Income Tax and a VAT, 105 TAx Notes 1651, 1652-59 (2004). Minor editing changes have been made to internal footnotes for consistency.

4. See William D. Andrews, A Consumption-Type or Cash Flow Personal Income Tax, 87 Harv. L. Rev. 1113 (1974).

5. See Alvin C. Warren, Fairness and a Consumption-Type or Cash Flow Personal Income Tax, 88 Harv. L. Rev. 931 (1975); William D. Andrews, Fairness and the Personal Income Tax: A Reply to Professor Warren, 88 HARv. L. Rev. 947 (1975). 
since it depends on using subjective utility rather than wealth as a measure of income. ${ }^{6}$

In the voluminous literature that followed, proponents of the consumption tax advanced three main arguments in its favor. ${ }^{7}$ First, they argued that it promotes efficiency by eliminating the deadweight loss from a tax on savings. Second, they argued that a consumption tax would boost national productivity by increasing national savings. Third, they argued that the consumption tax is considerably simpler than an income tax. ${ }^{8}$

Opponents of the consumption tax have replied that the supposed efficiency gains of the consumption tax are exaggerated and depend crucially on imposing a one-time tax on accumulated wealth at the time of the transition from the income to the consumption tax, which is politically highly unlikely to happen. Moreover, the added incentive to save under a consumption tax depends on the crucial assumption that people do not have a set savings goal, because if they did they would decrease, rather than increase, their savings rate in response to a reduction of tax on savings. Moreover, the empirical evidence is ambiguous at best in determining if tax decreases boost savings. Finally, the administrative advantages of the consumption tax depend crucially on its structure and may be lost if Congress built in exemptions like it did in the income tax. ${ }^{9}$

In recent years, the debate has shifted to three other issues, discussed more extensively below. First, proponents of the consumption tax (beginning with Prof[essors] Joseph Bankman and Thomas Griffith in 1992 and continuing more recently with Prof[essor] David Weisbach) have argued that the actual difference between it and the income tax is minimal because neither can reach risky returns, and risk-free returns on capital have historically been very low. ${ }^{10}$ Second, Prof[essor] Ed McCaffery has recently emphasized another point of similarity between a cash flow consumption tax and an income tax, in that they both reach inframarginal returns (rents), and therefore they can both be used to tax the rich, but the consumption tax is fairer because it taxes people only when they use their savings to enhance their lifestyle (and not when they use it to smooth their lifetime income patterns). ${ }^{11}$ Finally, Prof[essor] Dan[iel] Shaviro recently argued that a consumption tax can achieve the same degree of progressivity as the income tax, even though it does not appear to tax

6. Barbara H. Fried, Fairness and the Consumption Tax, 44 STAN. L. REv. 961 (1992).

7. See generally What Should Be TAXed: Income or Expenditure? (Joseph A. Pechman ed., 1980).

8. See, e.g., Blueprints, supra note 2; David F. Bradford, Untangling the InCOME TAX (1986); David F. Bradford, The Choice Between Income and Consumption Taxes, 16 TAX NotEs 715, 717-18 (1982).

9. See What Should Be TAXed: Income or Expenditure, supra note 7.

10. Joseph Bankman \& Thomas Griffith, Is the Debate Between an Income Tax and a Consumption Tax a Debate About Risk? Does it Matter?, 47 TAx L. Rev. 377, 387-88 (1992); David A. Weisbach, The (Non) Taxation of Risk, 58 TAx L. REv. 1, 31 (2004).

11. Edward J. McCaffery, [A New Understanding of Tax, 103 MICH. L. Rev. 807, 920 26 (2005)]. 
unconsumed income. ${ }^{12}$ Thus, proponents of the consumption tax argue that because the difference between an income tax and a properly structured consumption tax is minimal, but the consumption tax is administratively simpler than the income tax, it should be preferred.

One notable feature emerging from discussion is the near-universal assumption that a consumption tax must replace the income tax, rather than be imposed concurrently. And yet, every other OECD member country has both a consumption tax (the [Value Added Tax ("VAT")] in its various guises) and personal and corporate income taxes. Some OECD members have only added the consumption tax recently (Canada, Japan, Australia, Finland, and Switzerland are the most recent ones), but none have abolished their existing income tax upon doing so. ${ }^{13}$

The reason for this phenomenon is simple: The income tax is needed to tax the rich. As I will argue below, no consumption tax can tax unconsumed wealth, and unconsumed wealth needs to be taxed in a democratic polity to enable the government to achieve some degree of control over the economic, social, and political power of the rich. Thus, both a personal income tax and a corporate income tax are necessary tools of private power regulation in a modern society.

However, the income tax by itself is not enough. It is necessarily complex, and its revenue-raising potential is inherently limited both by administrability concerns and by the incentive effects of high tax rates. In addition, the income tax is limited by tax competition and the increasing ability of the rich (including large corporations) to shift their capital to other countries with lower tax rates, and its revenues are highly cyclical. Thus, to fund the social safety net, the government needs another tax instrument that can produce high levels of revenue at low administrative costs, and that is less dependent on cyclical shifts in economic activity. All over the world, in both developed and developing countries, the VAT has proven over the last [fifty] years to be ideally suited to this role. In fact, the rise and spread of the VAT since 1960 was the most important tax policy development in the [twentieth] century. As argued below, it is time for the United States to follow the rest of the world and adopt a VAT in addition to the corporate and personal income taxes. [Adopting the SIT Plan and a modified version of the business tax portion of the GIT Plan seems a workable way to implement this proposal.]

In this Part of the article, I propose to address three recent arguments in favor of replacing the income tax with a consumption tax.

12. Daniel Shaviro, Replacing the Income Tax with a Progressive Consumption Tax, 103 TAX Notes 91, 103-06 (2004).

13. For an excellent discussion of the VAT in the U.S. context see Charles E. Mclure, Jr., The Value Added Tax: Key to Deficit Reduction? (1987); see also Liam Ebrill et al., The Modern VAT (2001); Adrian Ogley, Principles of Value Added Tax (1998); Alan Schenk, Value Added Tax: A Model Statute and Commentary (1989); Alan Schenk \& Oliver Oldman, Value Added Tax: A Comparative Approach in Theory and Practice (2001); Alan A. Tait, Value Added Tax: International Practice and Problems (1988). 
Fundamentally, these arguments boil down to one assertion: The consumption tax is not meaningfully different than the income tax in terms of its progressivity or ability to tax the rich. Therefore, not much will be lost if the consumption tax is adopted, and the relative administrative simplicity of the consumption tax favors its adoption.

The three arguments in favor of equating the consumption and the income tax are (a) that neither can reach the returns on risky investments; (b) that both can reach inframarginal returns; and (c) that both can achieve identical progressivity. I will address each in turn. However, before turning to these arguments, it is necessary to reexamine the fundamental rationale for having an income tax in the first place.

\section{A. Why TAX Income?}

The individual income tax was adopted in the United States in 1913, when the [Sixteenth] Amendment empowered Congress to tax incomes and overturned the Supreme Court's Pollock [v. Farmers' Loan \& Trust] decision of 1895 , which held a previous attempt to tax incomes unconstitutional as a direct tax lacking apportionment. Before the [Sixteenth] Amendment was adopted, the federal government relied primarily on tariffs and excises for revenues, which served to protect American industry from competition and were imposed on consumption goods.

The principal argument in favor of replacing the consumptionbased tariff system with a personal income tax was that the tariffs were regressive. Because the poor consume a higher percentage of their income than the rich, a consumption tax is generally more regressive than an income tax. Economic developments in the late [nineteenth] and early [twentieth] centuries significantly increased the gap between rich and poor, and supporters of the income tax (primarily from the more agricultural states in the South and West) felt that the industrialists of the Northeast had grown rich behind protective tariffs and should bear a greater part of the burden of financing the government. In addition, state personal property taxes had notoriously failed to reach intangible types of property like stocks and bonds, further reducing the tax burden of the newly rich railroad, steel, and oil magnates.

I have argued elsewhere that the principal reason for taxing the rich today is similar to one of the major reasons why the personal and corporate income taxes were enacted in the early [twentieth] century: Both were perceived as having the potential of curbing excessive accumulations of political, economic, and social power by the rich. ${ }^{14}$

14. The following is based on Reuven S. Avi-Yonah, Corporations, Society, and the State: A Defense of the Corporate Tax, 90 Va. L. Rev. 1193 (2004). See also Reuven S. AviYonah, Why Tax the Rich? Efficiency, Equity, and Progressive Taxation, 111 Yale L.J. 1391, 1405-13 (2002) (reviewing Does Atlas Shrug? The Economic Consequences of TAXING THE RICH 524 (Joel B. Slemrod ed., 2000)). 
There are two principal arguments why a liberal democratic state should curb excessive accumulations of private power. The first is the argument from democracy (emphasis added): In a democracy, all power should ultimately be accountable to the people. Private accumulations of power are by definition unaccountable, since the holders of power are neither elected by the people nor have their power delegated from the people's representatives. In fact, the American Revolution was founded on the conception that while people have natural, Lockean liberal rights to their property, undue concentrations of private power and wealth should be discouraged. That view found its expression in the republican creed of civil humanism, which emphasized public virtue as a balance to private rights. A virtuous republic, the Framers believed, was to be free from concentrations of economic power such as characterized England in the eighteenth century. Therefore, from the beginning of the republic, federal and state legislators used taxation to restrict privilege and to "affirm communal responsibilities, deepen citizenship, and demonstrate the fiscal virtues of a republican citizenry." As Dennis Ventry has written,

[T] he ideal of civic virtue created a unique form of ability-to-pay taxation that was hostile to excess accumulation and to citizens who asserted entitlement through birth ..... Inherited wealth, as well as gross concentrations of wealth (inherited or not), characterized an aristocratic society, not a free and virtuous republic. ${ }^{15}$

In the [twentieth] century, the same view was best expressed in the corporate context by Berle, who wrote that in a democracy like the United States

[I]t becomes necessary to present a system (none has been presented) of law or government, or both, by which responsibility for control of national wealth and income is so apportioned and enforced that the community as a whole, or at least the great bulk of it, is properly taken care of. Otherwise the economic power now mobilized and massed under the corporate form . . . is simply handed over, weakly, to the present administrators with a pious wish that something nice will comes of it all. ${ }^{16}$

The other principal argument against excessive private power is based on a liberal conception of equality (emphasis added). Michael Walzer explained that when liberals talk about equality, they are not concerned with "simple equality," that is, equalizing everyone's initial means. ${ }^{17}$ Instead, they are advocating "complex equality," meaning that every social "sphere" should have its own appropriate distributive principles and that possession of goods relevant to one sphere should not automatically translate into dominance in other

15. Dennis J. Ventry, Equity Versus Efficiency and the United States Tax System in Historical Perspective, in Tax Justice: The Ongoing Debate 28 (Joseph J. Thorndike \& Dennis J. Ventry, Jr. eds., 2002).

16. A. A. Berle, For Whom Corporate Managers Are Trustees, 45 HaRv. L. REv. 1365, 1368 (1932).

17. Michael Walzer, Spheres of Justice: A Defense of Pluralism and EqualITY (1983). 
spheres as well. "In formal terms, complex equality means that no citizen's standing in one sphere or with regard to one social good can be undercut by his standing in some other sphere, with regard to some other good." 18 In our capitalist society, money is the "dominant good," and the people who possess it are the most likely to accumulate illegitimate power in other spheres, such as politics. "This dominant good is more or less systematically converted into all sorts of other things- opportunities, powers, and reputations." 19 Walzer goes on to explain the insidious effects of money and why it needs to be curbed by redistribution, including redistributive taxation:

Market imperialism requires another sort of redistribution, which is not so much a matter of drawing a line as of redrawing it. What is at issue now is the dominance of money outside its sphere, the ability of wealthy men and women to trade in indulgences, purchase state offices, corrupt the courts, exercise political power ... the exercise of power belongs to the sphere of politics, while what goes on in the market should at least approximate an exchange between equals (a free exchange) .... When money carries with it the control, not of things only but of people, too, it ceases to be a private resource. ${ }^{20}$

Nor, as we have noted above, is the power of money limited to direct political power:

It would be a mistake to imagine, however, that money has political effects only when it "talks" to candidates and officials .... It also has political effects closer to home, in the market itself and in its firms and enterprises .... Even within the adversary relation of owners and workers, with unions and grievance procedures in place, owners may still exercise an illegitimate kind of power. They make all sorts of decisions that severely constrain and shape the lives of their employees (and their fellow citizens, too). Might not the enormous capital investment represented by plants, furnaces, machines, and assembly lines be better regarded as a political than an economic good? To say this doesn't mean that it can't be shared among individuals in a variety of ways, but only that it shouldn't carry the conventional entailments of ownership. Beyond a certain scale, the means of production are not properly called commodities ... for they generate a kind of power that lifts them out of the economic sphere. ${ }^{21}$

Walzer thus advocates taxation as one means of restricting the market to its proper sphere (along with trade unions and limiting property rights), but he also recognizes the inherent limitations of all redistribution, since his aim is not to abolish the market:

All these redistributions redraw the line between politics and economics, and they do so in ways that strengthen the sphere of politics- the hand of citizens, that is, not necessarily the power of the

18. Id. at 19 .

19. Id. at 12 .

20. Id. at 120-21.

21. Id. at 121-22. 
state .... But however strong their hand, citizens can't just make any decisions they please. The sphere of politics has its own boundaries . . . . Hence redistribution can never produce simple equality, not so long as money and commodities still exist, and there is some legitimate social space within which they can be exchanged. ${ }^{22}$

The personal income tax is one means by which the state can regulate the accumulation of private power. As I have argued elsewhere, the tax achieves this function in two ways: by directly limiting the rate of private wealth accumulation (the limiting function), and by providing incentives and disincentives to particular activities by the rich (the regulatory function). For reasons explained below, both functions are necessary and related to each other, in the same way that both a brake and a steering wheel are necessary for driving a car. ${ }^{23}$

First, the limiting function: Imagine first a 100[\%] tax imposed on profits. Over time, such a tax would eliminate all sources of power of the rich, since it would force them to use their existing resources to pay politicians and employees, and it would remove any incentive to accumulate further wealth. The power to tax is indeed potentially the power to destroy.

But a $100[\%]$ tax is inconceivable. Taxation faces an inherent limit that was well expressed by Justice Holmes when he stated that "the power to tax is not the power to destroy while this [C]ourt sits."

The constitution places limits on the power to tax, limits that are implicit already in Dartmouth College: The public sector may not use taxation to completely eliminate the private one. This is both a matter of constitutional law (a tax may be a taking if the rate exceeds any reasonable estimate of the state's contribution to private wealth creation) and a matter of practicality: We do not want to kill the goose that lays the golden eggs by imposing taxation at rates that create huge deadweight losses to the economy at large (the deadweight loss is approximately a square function of the tax rate). The precise limit of desirable taxation thus becomes the quintessential political question of our time, to be refought every four years at the ballot box.

Given that we cannot tax at $100[\%]$, what is the effect on private power of a lower tax rate, such as the current $35[\%]$ ? Even at that historically low rate, the income tax does significantly slow down the accumulation of private resources, which are the foundation of private power. For example, imposing a tax of 35[\%] on assets invested at a 10[\%] yield (compounded annually) over ten years results in approximately $27[\%]$ less assets being available at the end of the period than would be available in the absence of the tax. Thus, taxation at lower rates can meaningfully restrict the build-up of assets that form the power base of the rich, even when it does not destroy it. But since that power could continue to exist and grow at any reason-

22. Id. at 122-23.

23. See Avi-Yonah, Corporations, Society, and the State: A Defense of the Corporate Tax, supra note 14 , at $1246-49$. 
able rate of taxation, we also need the tax to perform a regulatory function.

Second, the regulatory function: The use of assets by the rich (that is, their use of power) may be impacted by the threat that the tax rate will be raised if it is perceived that the assets are not used for the betterment of society. That can be seen by the imposition of higher effective rates on certain forms of behavior Congress disapproves of, like bribes paid to foreign officials and participation in international boycotts. In both cases, empirical research has suggested the tax penalties had a significant impact. More recently, the threat of increased tax rates applied to United States corporations that moved their nominal place of incorporation to Bermuda seems to have sufficed to block one such "inversion" transaction and stop other corporations from adopting the same strategy. Thus, it seems that taxation even at rates much less than $100 \%$ can suffice to regulate private power. But the rates cannot be set too low, because then the rich would not care sufficiently to avoid the tax. That is why we need the limiting function (that is, set rates at sufficiently high levels for management to notice) for the regulatory function to work properly.

Finally, in addition to providing disincentives, the tax can be used to provide incentives as well. For example, investment incentives are provided as a way of bolstering the economy. Another example is research and development, which has been shown by economists to produce significant positive externalities for society that justify the government in providing a subsidy via the tax code. Now, it is of course true that the government could subsidize these functions directly, rather than use tax expenditures, so this cannot strictly be an argument for taxing the rich. However, that would require setting up an IRS-like agency to monitor the use of the subsidies, so that any simplification advantage gained from abolishing the income tax is diminished. And once the income tax is in place, it seems like an obvious and convenient vehicle to deliver the desired subsidies at little additional cost.

Is the income tax the best vehicle for curbing excessive private power accumulation? An obvious alternative would be a direct wealth tax. However, in addition to concerns about its constitutionality, it is questionable whether a wealth tax is administrable. Intangible forms of property proved difficult to tax in the [nineteenth] century, and are probably even harder to tax today, since the valuation of non-publicly traded property is a very difficult enterprise. In particular, the rise of financial derivatives makes it hard even for sophisticated financial institutions to value their assets for financial reporting purposes. In addition, political experience since 1972 has shown that the American people are very averse to paying taxes on property, as indicated by the wave of property tax limitations and the unpopularity of the estate tax. Thus, the income tax remains the best way to reach the sources of power of the rich, assuming that it can do so. 


\section{B. Risk: Is There a Meaningful Difference?}

Can the income tax in fact tax the rich, or to put it another way, can it tax income from capital? If it cannot, then a strong argument can be made for replacing it with a consumption tax on administrative grounds, because if income from capital cannot be taxed, an income tax has the same base as a consumption tax but is immensely more complicated (for example, because it needs to account for basis).

Beginning with Bankman and Griffith in 1992, a significant body of legal literature has argued that the difference between income and consumption taxes is minimal, and therefore the consumption tax should be preferred on administrative grounds. Most recently, David Weisbach has argued that:

[A] Haig-Simons tax is basically the same as a consumption tax (which imposes a zero tax on capital), and the debate between the two tax bases is not particularly meaningful. The decision might best be made on administrative grounds rather than on deep philosophical arguments about the proper distribution of the tax burden. ${ }^{24}$

The argument relied on by Bankman, Griffith, and Weisbach is based on an observation made by Domar and Musgrave in 1944, and expanded by many economists since then. Domar and Musgrave pointed out that if an individual is subject to a (say) 50[\%] income tax on risky returns, he can eliminate that tax by increasing the amount invested, because the government shares equally in both his gains and his losses. Thus, suppose the individual makes a bet of $\$ 100$ with an equal chance of winning and losing (for example, a coin flip). Before tax, the individual would receive $\$ 100$ if he wins and would pay $\$ 100$ if he loses. If the government imposes a 50[\%] HaigSimons income tax, the individual would only receive $\$ 50$ if he wins (since he pays $\$ 50$ in tax to the government) but would only lose $\$ 50$ if he loses (since the government would in effect pay him $\$ 50$ by allowing him to deduct the $\$ 100$ loss at a 50[\%] tax rate). But if he could double the bet to $\$ 200$, he would get $\$ 100$ if he wins and pay $\$ 100$ if he loses, putting him in the same position he was in if the tax was not imposed at all.

Bankman, Griffith and Weisbach expand this proposition to argue that a Haig-Simons income tax cannot be imposed on risky returns. They then go on to demonstrate that if the income tax can only be imposed on risk-free returns, since these have historically been very low (around $0.5[\%]$ ), the difference between an income tax and a consumption tax is so minuscule as to not be worth the argument.

Various commentators have recently taken issue with this line of argument. Thus, Prof[essor] Reed Shuldiner argues that the model is misleading for several reasons. ${ }^{25}$ First, in the case of investments rather than bets, grossing-up the investment is not costless: it involves both transaction costs and credit risk, since even rich individu-

24. Weisbach, supra note 10 , at $2-3$; see generally Bankman \& Griffith, supra note 10 .

25. Reed Shuldiner, Taxation of Risky Investments (unpublished manuscript on file with author). 
als cannot borrow at the risk-free rate of return. Second, he argues that the risk-free rate used by Bankman and Griffith is too low, because they used the period from 1945 to 1972 , in which unexpected inflation was high; from 1972 to 1999 the risk-free rate was $1.5[\%]$, and from 1802 to 1997 when it was 2.9[\%]. Moreover, the term of the rate is important: It should match the term of the investment, and the real risk-free rate for 1972 to 1999 on [ten] year investments was $3.3[\%]$. Thus, the difference between the income and consumption tax, even on the assumptions underlying the Domar-Musgrave model, is more significant than previous commentators have assumed.

In addition, both Shuldiner and Professor Larry Zelenak point out that the key assumptions underlying the model may not be accurate. ${ }^{26}$ First, individuals do not always behave with the kind of perfect rationality assumed by the Domar-Musgrave analysis. Second, we do not have a Haig-Simons income tax, as assumed in the model, because there are various loss limitations imposed by the income tax.

First, individual behavior: Various empirical studies have attempted to examine whether individuals adjust their portfolios in the ways required for the Domar-Musgrave analysis to be correct, such as Weisbach's survey of this literature and conclusion that "the empirical evidence is insufficient to sway us one way or another."27 More broadly, economists have studied generally how sensitive the behavior of the rich is to taxes and concluded that, in many cases, that sensitivity is surprisingly low. For example, in most of the empirical studies in Joel Slemrod's book on taxation and the rich, the expected tax avoidance behavior either did not materialize or was lower than expected. ${ }^{28}$ There are many considerations that influence individual behavior beyond taxes, and transaction costs make a difference as well. Because the consumption tax advocates are using the Domar-Musgrave result to advocate a radical change in our tax law, it seems to me that the burden should be on them to show that the risky returns are in fact not reached by the income tax, rather than (as Weisbach suggests) on the advocates of the income tax to show that the Domar-Musgrave model is incorrect.

Second, loss limitations: The existing income tax imposes various limitations on losses, such as the at-risk, passive activity and capital loss limitations. In addition, it imposes graduated (progressive) tax rates, so that losses can sometimes be deducted at different rates than the rates applied to income. All of these limitations violate the Domar-Musgrave assumptions and result in a positive tax rate being imposed on the return to risk under the existing income tax.

Various critics have rejected this argument on the ground that it is hard to find a normative justification for the particular pattern of taxing risk imposed by these limitations, except perhaps for progres-

26. Id:; Larry Zelenak, The Sometimes-Taxation of the Returns to Risk-Bearing Under a Progressive Income Tax (unpublished manuscript on file with author).

27. Weisbach, supra note 10 .

28. See Does Atlas Shrug? The Economic Consequences of Taxing the Rich (Joel Slemrod ed., 2000). 
sive rates. In addition, Weisbach argues that this issue is irrelevant because the debate is about comparing Haig-Simons taxation to a consumption tax, not about the current income tax.

However, the key question in this debate is not whether we do or do not have a perfect income tax. The key issue is whether the existing income tax succeeds in taxing the rich in ways that a real consumption tax would not. A tax is just a means to an end, not an end by itself. If the purpose of having an income tax like the one we have is to tax the rich, as argued above, the key issue is whether it succeeds in doing so.

There is abundant empirical evidence that the income tax does in fact tax the rich. First, according to 2001 IRS data, the top 1[\%] of the United States population by adjusted gross income paid 33.89[\%] of federal personal income tax, and the top 5[\%] paid 53.25[\%] (by comparison, the bottom 50[\%] of the AGI distribution paid less than $4[\%]$ of total income taxes collected). This is a significant increase from 1994, when the top 1 [\%] of taxpayers only paid 28.7 [\%] of federal personal income tax. ${ }^{29}$ In 2004, even after President Bush's tax cuts, the top 1[\%] still paid 32.3[\%] of federal individual income taxes and the top 5[\%] paid 53.7[\%]. ${ }^{30}$ Because (as indicated below) a very large portion of the income of the rich consists of risky returns, it is hard to explain these patterns if risky returns are in fact exempt from tax.

Second, it appears likely that these significant payments by the rich are in large part the result of taxing risky returns to capital, not labor income or non-risky returns. There is a strong correlation between wealth and the percentage of an investor's portfolio allocated to risky assets, so it is likely that a significant portion of the rich's income derives from risky assets. Specifically, the percentage of income from equity investments (dividends and capital gains), which are the most common type of risky asset, increases from 4 [\%] for taxpayers with income of $\$ 100,000$ or less to $11.5 \%$ for taxpayers with income from $\$ 100,000$ to $\$ 500,000,24.7[\%]$ for income between $\$ 500,000$ and $\$ 1$ million, 37.6[\%] for income between $\$ 1$ and $\$ 10$ million, and an impressive $61.4[\%]$ for taxpayers whose income exceeds $\$ 10$ million. ${ }^{31}$ Another indication that the income tax does reach risky returns is that total revenues from the federal personal income tax rose dramatically in the Internet bubble of the late 1990s, and fell dramatically as the bubble burst in 2000 . Most of that rise and fall is attributable to realizations of risky assets in the bubble years.

It is not entirely clear why the return on risky assets is taxed under the existing income tax. A combination of loss limitations and limitations on investor behavior (such as transaction costs, credit risk, and myopia) may explain the observed pattern. However, the key issue is

29. Press Release, J. Econ. Comm., Congress of the United States, New IRS Data on Income \& Tax Shares Now Available (Sept. 26, 2003), available at http://www.house.gov/ jec/press/2003/09-26-03b/pdf.

30. Congressional Budget Office, Effective Federal Tax Rates Under CurRENT LAw, 2001-2014, 11, tbl. 2 (2004), available at http://www.cbo.gov/ftpdocs/57xx/ doc5746/08-13-EffectiveFedTaxRates.pdf.

31. Tax Policy Center (2004). 
not why this result occurs but that it does, in fact, occur. The burden should be on the advocates of radical tax reform to show that the existing income tax (and not some theoretical construct like HaigSimons) fails to tax the rich on risky returns. It is, after all, the existing income tax that they seek to replace, not some ideal tax. If they can show that the top $1[\%]$ by AGI will continue to bear over a third of the total burden of a consumption tax, then the reform would be more acceptable to those who believe in taxing the rich for the reasons stated above (or any other reasons).

Moreover, it seems to me that this distribution of the burden makes the existing income tax normatively attractive even if its particular rules operate in sometimes erratic ways. Thus, I disagree with Prof[essors] Deborah Schenk and Larry Zelenak, who argue that the existing tax on capital is too unpredictable to be normatively attractive. ${ }^{32}$ We should look at the tax burden and its meaning from an aggregate, not from an individual perspective. A tax that is as progressive in its overall outcome as the existing income tax is worth defending, even if its rules lead to strange results in individual cases. The key issue is the ultimate burden imposed on the rich, not the particular rules of the tax (progressivity, loss limitations, and the like).

Finally, a word of caution is in order. The risk argument advanced by Bankman, Griffith and Weisbach bears a lot of similarity to the argument used (for example, by Weisbach) to justify the adoption of the check-the-box rule in 1997 for classifying foreign entities as branches, partnerships, or corporations. Weisbach and others argued that taxpayers can achieve any result they want under the existing classification rules, so that it would save administrative costs to replace these rules with a simple election. ${ }^{33}$ The results of this radical reform were catastrophic: It turns out that a vastly higher number of taxpayers made check-the-box elections and used classification to avoid the international tax rules. Apparently, there were significant transaction costs imposed under the pre-1997 regime that prevented taxpayers from achieving like results. This episode should lead us to be very cautious in relying on theoretical constructs like the DomarMusgrave model to advocate replacing the income tax with a consumption tax because they are "just the same." For whatever reasons, the current income tax succeeds in taxing the rich. It is highly doubtful that any consumption tax would achieve the same outcome (although as we will see below, some are better than others).

\section{Rents: Prepaid vs. Postpaid Taxes}

Much of the consumption tax literature relies on the familiar Cary Brown theorem, which is studied in every basic tax class. The Cary Brown theorem demonstrates the theoretical equivalence, under cer-

32. See Zelenak, supra note 26; Deborah H. Schenk, Saving the Income Tax with a Wealth Tax, 53 TAx L. ReV. 423 (2000).

33. See David A. Weisbach, Line Drawing, Doctrine, and Efficiency in the Tax Law, 84 Cornell L. Rev. 1627 (1999). 
tain assumptions, of prepaid and postpaid consumption taxes in exempting the return on capital from tax. In a prepaid tax, the tax is paid when the income is earned, just as in an income tax, but investment returns are exempt from tax. In a postpaid tax, a deduction is available for savings, so that income that is saved is not taxed, but investment returns are taxed when they are consumed.

To take a common example, suppose a taxpayer earns $\$ 100$ subject to a tax of $50[\%]$ and can invest it in a bond earning $10[\%]$ per year. Under an income tax, the $\$ 100$ of earnings are subject to a tax of $\$ 50$, and the remaining $\$ 50$ are invested in the bond, yielding $\$ 55$ after 1 year; the $\$ 5$ of interest is subject to income tax (Mill's "double tax") leaving the taxpayer with only $\$ 52.50$.

In a prepaid consumption tax, the $\$ 100$ of income is subject to tax of $\$ 50$ when earned. The remaining $\$ 50$ is invested in the bond, but when the additional $\$ 5$ of interest is earned, they are exempt from tax, so that the taxpayer is left with $\$ 55$.

In a postpaid consumption tax, the $\$ 100$ of income is saved, and the resulting deduction eliminates the tax on the $\$ 100$, so that the taxpayer can invest the entire $\$ 100$ in the bond. However, when the bond is sold for $\$ 110$ a year later and the $\$ 110$ is consumed, it is subject to tax at $50[\%]$, leaving the taxpayer with the same $\$ 55$ as in the previous example.

Hence, the Cary Brown theorem demonstrates that prepaid and postpaid consumption taxes are equivalent, and both exempt the $\$ 5$ return on the bond from tax. Since income from capital is exempt under the Haig-Simons definition of income, both pre- and postpaid consumption taxes are also theoretically equivalent to a direct tax on consumption like the Retail Sales Tax ("RST").

The Cary Brown theorem makes two important assumptions. The first is that tax rates do not change between the time the income is saved and the time it is consumed. If the tax rates change, the equivalence of prepaid and postpaid consumption taxes does not hold, because a prepaid tax applies the rate at the beginning of the year and a postpaid tax applies the rate at the end. However, this assumption may not matter too much, since rates can either increase or decrease over time, so it is unclear which form of the tax is more beneficial to the taxpayer.

The other assumption, however, has clear implications. That is the assumption that the taxpayer can invest the savings from taking the tax deduction in a post-paid tax at the same rate as the underlying investment. That holds true when the investment is a commonly available one like a bond, yielding what the economists call marginal (normal) returns. However, suppose the underlying investment is in a unique business opportunity, yielding what the economists call infra-marginal (extraordinary) returns, or rents. In that case, the investor may not be able to invest the tax savings at the same rate as the underlying investment because the size of the unique investment opportunity is limited, and the Cary Brown equivalence does not hold.

For example, suppose in the example above the underlying investment yields a $50[\%]$ return but the tax savings can only be invested 
in a bond earning $10[\%]$. In a pre-paid tax, the taxpayer earns $\$ 100$, pays $\$ 50$ in tax, and invests the other $\$ 50$ in the high-yielding opportunity, resulting after a year in a $\$ 25$ return exempt from tax, for an after-tax net of $\$ 75$. In a post-paid tax, the investor earns $\$ 100$ and does not pay tax because of the deduction for savings; however, of the $\$ 100$, only $\$ 50$ can be invested at a return of $50[\%]$, and the other $\$ 50$ (the tax savings) is invested at $10[\%]$. The result is a yield after a year of $\$ 75$ from the underlying investment and $\$ 55$ from the tax saving, for a total of $\$ 130$, and when it is consumed and is subject to tax at 50[\%], the taxpayer nets only $\$ 65$. To put it another way, in a postpaid tax, only the normal yield is exempt from tax; the extraordinary yield is fully taxable.

Ed McCaffery uses this result to argue for a post-paid consumption tax. ${ }^{34}$ In his view, such a tax is not only superior to an income tax because it does not tax the normal return on savings, but it is also superior to a prepaid consumption tax because it does reach extraordinary returns on savings when they are consumed. Or, to put it in other terms, the tax is deferred when savings are used to smooth income over a lifetime, but imposed when the savings are consumed above the return necessary for such smoothing.

While I disagree with McCaffery about taxing unconsumed earnings, for the reasons explained above (and elaborated further below), I agree with him regarding the superiority of postpaid over prepaid consumption taxes because of their ability to reach rents. Rents should be subject to high taxation in part because they are hard to replicate (and thus the deadweight loss from taxing them is small) and in part because they depend on luck (such as the distribution of various talents). The key issue is how common are such rents. There is abundant literature suggesting that rents are common for corporations and that may be why most serious consumption tax proposals (but not all of them) support a postpaid (cash flow) consumption tax for corporations.

However, there is also evidence that in a "winner take all" society, rents are commonly earned by individuals as well. Consumption tax advocates sometimes argue that such rents are a form of labor income, not income from capital. Thus, the extraordinary returns earned by Bill Gates or Warren Buffett presumably result from their skill and luck and not primarily from capital invested (which in the case of Gates was minimal). However, it seems immaterial whether such rents earned by individuals are capital or labor income. They key issue is to ensure that they are taxed and while the current income tax does not do a very good job in taxing them (primarily due to the realization requirement), it does a better job than a pre-paid consumption tax that exempts such rents altogether. Whether a postpaid consumption tax can reach them depends on whether they are in fact consumed, which I will discuss below. For now, it is important to remember that only post-paid consumption taxes can reach rents, because that is a key issue in differentiating among the various tax reform proposals currently advanced.

34. McCaffery, supra note 11. 


\section{Can a Consumption Tax Be Progressive?}

Many consumption tax advocates argue that a properly structured consumption tax can be just as progressive as the income tax. The most promising candidate from this perspective is a postpaid consumption tax, because as we have seen it can impose progressive rates on both labor income and on rents when those are consumed. On the other hand, transactional consumption taxes like the RTS cannot generally be progressive since they are imposed at a uniform rate and since the poor consume a higher proportion of their income than the rich. Nor can prepaid consumption taxes be as progressive because they exempt rents even when those are consumed.

The key issue regarding regressivity is whether any consumption tax, even a postpaid one, can be as progressive as an income tax, given that it does not by definition reach income that is not consumed. The super-rich do not consume a significant portion of their income during their lifetime and an income tax can in principle tax these earnings (or at least the risk-free portion of them) whereas even a post-paid consumption tax does not. ${ }^{35}$

Dan Shaviro argues that this perception is mistaken because a consumption tax will always tax income whose consumption is deferred, even if it is deferred for a long time. He gives an example of taxpayers $A$ and $B$ who both consume $\$ 100,000$ in a given year, but $A$ has spent everything she earned whereas $B$ has saved $\$ 1$ million in the bank. Assuming a 50[\%] consumption tax rate and 10[\%] interest rate, $A$ presumably earned $\$ 200,000$ and $B$ earned $\$ 1.2$ million, and each paid $\$ 100,000$ in tax. $B$ 's remaining $\$ 1$ million grows to $\$ 1.1$ million and when it is consumed $B$ pays $\$ 550,000$ in tax. Shaviro points out that this is the same additional $\$ 500,000$ in tax liability $B$ would have had had she consumed everything in year 1 , increased by the interest rate of $10[\%]$ to take into account the one-year deferral. Thus, $A$ and $B$ are in fact treated the same.

More generally, Shaviro argues that any income is only worth what it can buy; "otherwise, it might as well be play money from the board games Monopoly or Life." Thus, it is wrong to argue that a consumption tax fails to reach the indirect benefits of wealth-holding, such as security, political power, or social standing; this nonsequitur "appears to rest on money illusion, or the mistaken belief that a dollar has inherent value, rather than being worth what it can buy." 36

However, this argument ignores the fact that money can be used for things other than consumption. Most importantly, it can be used to acquire investments - both financial and real - such as manufacturing plants. And the key point made above is that the power of the rich, which is (in my view) the principal target of the income tax, rests primarily on their ability to invest, not to consume. For example, it is the ability of corporations to choose which locations to open plants and create jobs that makes politicians so solicitous of their

35. Theoretically, leaving accumulated wealth to one's heirs can be defined as a form of consumption, but none of the current consumption tax proposals do so.

36. Shaviro, supra note 12. 
welfare - more, in fact, than their direct political contributions. But even in the case of political contributions, it is unclear whether those will be reached by a consumption tax, because it can persuasively be argued that these are a form of investment rather than consumption. Thus, a consumption tax will only reach the small percentage of the power held by the rich that depends directly on their ability to consume, such as their personal employees or businesses that provide consumer goods to them. It will not reach the much larger percentage of their power that depends on their ability to invest.

Theoretically, therefore, no consumption tax can achieve the goals of progressivity, which I have argued above are to curb the power of the rich, as well as an income tax. This does not mean that the current income tax does a very good job, although it appears from the data cited above to be quite progressive. Perhaps a consumption tax that taxes labor income at sharply graduated rates and also reaches actual consumption of saved income can be as progressive as the current income tax. ${ }^{37}$ However, the burden should be on consumption tax advocates to show that this is indeed the case; the distributive tables of President Bush's steps toward a consumption tax suggest otherwise. In addition, the income tax, because it reaches unconsumed income, can be made more progressive in ways that a consumption tax cannot, because it can reach the main source of the power of the rich - their unconsumed wealth.

The most striking fact about the Report as a whole is that it refused to recommend proposals (like the national sales tax, the VAT, or a progressive cash flow tax) to replace the income tax with a pure consumption tax. ${ }^{38}$ Of the two plans proposed, the SIT Plan, as its name indicates, is an income tax, while even the GIT Plan, which is based on David Bradford's "X-Tax" proposal, incorporates taxation of savings at the individual level. ${ }^{39}$ I believe the principal reason for this resiliency of the income tax is the distributive impact of the proposal, and the political unacceptability of any proposal that completely exempts income from savings. As I have argued elsewhere, any proposal that does not tax income from savings fails to achieve the distributive and regulatory functions of the income tax, and thus is unlikely to be enacted..$^{40}$

37. One should note, however, that the sharply graduated rates of such a tax come at a price, namely increased pressure on the labor/leisure tradeoff.

38. See generally REPORT, supra note 1.

39. See generally David F. BRAdFord, Untangling the Income Tax, supra note 8 ; David F. Bradford, Consumption Taxes: Some Fundamental Transition Issues, in FroNTIERS OF TAX REFORM (Michael J. Boskin ed., 1996). 2006).

40. Reuven S. Avi-Yonah, The Three Goals of Taxation, Tax L. Rev. (forthcoming 


\section{THE REPORT PROPOSALS: TAXATION OF INDIVIDUALS ${ }^{41}$}

The basic premise of the Panel's recommendations for individuals involves the broadening of the tax base, removing some of the complexity in the rules, eliminating the AMT, and eliminating most tax deductions and preferences, coupled with a reduction in the number of individual tax brackets. Under the SIT Plan, the number of brackets would be reduced from the current six to four $(15 \%, 25 \%, 30 \%$, and $33 \%)$. Under the GIT Plan, the number of tax brackets would be reduced from six to three $(15 \%, 25 \%$, and $30 \%) .{ }^{42}$

Under both Plans, the standard deduction, personal exemptions, child tax credit, and head of household filing status would be consolidated into a "family credit." 43 The base credit amount would equal $\$ 1,650$ for single filers; $\$ 3,300$ for married filers; $\$ 2,800$ for single filers with dependent children; and $\$ 1,150$ for dependent taxpayers. ${ }^{44}$ To that base amount, each family would add $\$ 1,500$ for each dependent child and $\$ 500$ for each other dependent, and those amounts would be adjusted annually for inflation. ${ }^{45}$ The tax preferences for higher education costs also would be simplified by replacing the current credits and deductions with a full family credit allowance of $\$ 1,500$ for all families with full-time students age 20 and under. ${ }^{46}$ Under both Plans, the popular itemized deduction for state and local taxes would be eliminated. ${ }^{47}$

In addition, both Plans would consolidate the current earned income tax credit and refundable child tax credit into a single "work credit." 48 As under the current system, the work credit amount would increase as the amount of earnings from work (wages and self-employment income) increases, and the rate and maximum credit amount would be higher for workers who live with qualifying children. ${ }^{49}$ For the first year, the work credit maximum amount would be $\$ 412$ for workers with no children; $\$ 3,570$ for workers with one child; and $\$ 5,800$ for workers with two or more children. The work credit would be adjusted annually for inflation. ${ }^{50}$

Both Plans would allow all taxpayers to claim a deduction for charitable contributions that exceed one percent of income, and the Plans would

41. The descriptive sections that follow are based on the REPORT, supra note 1, and on ERnst \& Young, Reworking the Code? Overview and Analysis of the Tax REFORM PANEL's REPORT (2005), available at http:/www.ey.com/global/download.nsf/us/ tax_reform_guidel\$file/tax_reform_guide11-2005_lckd.pdf [hereinafter ERNST \& YounG REPORT].

42. REPORT, supra 1 , at 61 .

43. Id. at 65 .

44. Id.

45. Id.

46. Id. at 84 .

47. Id. at $61,63-67$.

48. Id. at 68 .

49. Id. at 68-69.

50. Id. at $61,68-69$. 
allow taxpayers over age sixty-five to contribute distributions from individual retirement accounts to qualified charitable organizations without incurring tax liability. ${ }^{51}$ The Plans would also allow taxpayers to sell appreciated property without recognizing a gain and receive a full charitable contribution deduction if all the proceeds are donated to a charity within sixty days of the sale. ${ }^{52}$

To improve documentation of charitable contributions, the Plans would require charities to report large gifts ( $\$ 600$ or higher in annual contributions) directly to the IRS and to the donor. ${ }^{53}$ All cash and noncash contributions of $\$ 250$ or more would count toward the $\$ 600$ threshold. ${ }^{54}$ The Panel recommended exempting from the information reporting requirements small charities that do not receive more than 250 contributions of $\$ 600$ or more or total contributions of more than $\$ 150,000.55$

For noncash contributions, the Plans would recommend new rules requiring appraisals, establishing standards for qualified appraisers, and requiring appraisers to report the value of contributed property to the IRS as well as to the donor and the charity. ${ }^{56}$ The Plans also would recommend increasing penalties on appraisers who misstate, by more than fifty percent, the value of property. ${ }^{57}$

To curb abuses associated with current self-reporting of the value of clothing and household items, the Panel recommended allowing the deduction for those contributions only when the taxpayer receives a price list and itemized receipt from the charity. ${ }^{58}$

The Panel made no specific recommendations on the rules governing exempt organizations, but recommended generally greater oversight and better governance of them. ${ }^{59}$

One of the more controversial proposals made in the two options would convert the current home mortgage interest deduction into a "home credit" equal to fifteen percent of the interest paid on the mortgage on a primary residence. ${ }^{60}$ The Panel recommended limiting that credit to interest on a standard principal amount. ${ }^{61}$ That standard amount would vary by region of the country and would be adjusted annually to reflect variations in home prices. ${ }^{62}$ Thus, if home prices rise, so too would the taxpayer's limit under the home credit. ${ }^{63}$

51. Id, at 75-76.

52. Id at 77 .

53. Id. at 76 .

54. Id. at 239 .

55. Id.

56. Id. at $76,239$.

57. Id. at 239 .

58. Id. at 78 .

59. Id.

60. Id. at 73 .

61. Id. at 237 .

62. Id.

63. Id 
The cap on the eligible mortgage indebtedness would be tied to the ceilings, that are determined using median home prices provided on a county-by-county basis, the Federal Housing Administration (FHA) sets for the amount of a home mortgage loan that it will insure. ${ }^{64}$ Under the Plans, those amounts would be adjusted to reverse a discount the FHA applies and to account for the difference between median and average prices. To determine mortgage loan limits, the amount the FHA reports would be grossed up to $100 \%$ of median values and then increased by $125 \% .{ }^{65}$ According to the Panel's report, if the credit was in place today, the limits would be between approximately $\$ 227,147$ and $\$ 411,704 .^{66}$

The Panel recommended phasing in those changes over a five-year period.67 During the transitional period, taxpayers would be allowed to claim either the home credit or the mortgage interest deduction on existing mortgages. ${ }^{68}$ The current-law $\$ 1$ million mortgage interest limit would be reduced annually during the five-year transition period. ${ }^{69}$ Interest on a second home or a home equity loan would not be eligible for transition relief, and the deduction would be repealed after the effective date. ${ }^{70}$ Interest on new or refinanced mortgages would not qualify for the transitional mortgage interest deduction, but would be eligible for the new home credit. ${ }^{71}$

Both Plans would retain a modified version of the exclusion for gains on the sale of a primary residence by setting the exclusion at $\$ 600,000$ for joint filers ( $\$ 300,000$ for single filers) and indexing that level for inflation. ${ }^{72}$ Gains greater than that amount would be taxed at ordinary income rates under the SIT Plan and at fifteen percent under the GIT Plan. ${ }^{73}$ The Panel also recommended applying the exclusion only if a taxpayer occupies the residence for three of the last five years (rather than two of the last five years)..$^{74}$

The Panel recommended allowing employers to continue deducting the cost of employee compensation, whether in the form of cash compensation or health insurance premiums. ${ }^{75}$ Further, the Panel recommended allowing workers to purchase insurance either through their employer or on their own with pretax dollars up to the average cost for health insurance. ${ }^{76}$ Taxpayers who do not have access to employer-provided plans would be allowed a new deduction for health premiums equal to the ex-

64. Id.

65. Id.

66. Id.

67. Id. at $74,238$.

68. Id. at 238 .

69. Id.

70. Id.

71. Id.

72. Id. at 126 .

73. Id at 126 .

74. Id. at 126 .

75. Id. at 81 .

76. Id. 
clusion available to workers whose employers provide health insurance. ${ }^{77}$ The Panel recommended limiting the exclusion to the average amount projected to be spent on health insurance premiums. ${ }^{78}$ For 2006 that amount would be $\$ 11,500$ for families and $\$ 5,000$ for individuals. ${ }^{79}$ The limit would be adjusted for annual increases in overall inflation, rather than health inflation. ${ }^{80}$

In addition to the changes related to health benefits, both Plans would make significant changes to the definition of taxable compensation for employees. Specifically, employer-provided fringe benefits, like educational assistance, child-care benefits, group-term life insurance, and longterm care insurance, which now are excludable, would be taxable to the employee. ${ }^{81}$ The value of "in-kind" benefits provided to all employees (for example, meals at a company cafeteria) would continue to be excludable. ${ }^{82}$ The employer's deduction for compensation would not change. The additional taxable compensation would be subject to both income and payroll taxation. ${ }^{83}$

Both reform Plans include a four-pronged savings package that the Panel recommended should move forward as a unified whole to have the desired effects on the personal savings rate. The Plans include three savings vehicles-a Save at Work account, a Save for Retirement account, and a Save for Family account. ${ }^{84}$ The Plans also include a refundable savers credit. ${ }^{85}$ The Plans would not change the current defined benefit plan rules. 86

The Save at Work accounts, which track the Bush administration's employer retirement savings account proposal, would replace many current employer-defined contribution plans and would simplify the current nondiscrimination rules, which are designed to ensure that the plans are not biased in favor of highly compensated employees. In general, Save at Work accounts would follow the existing contribution limits and rules for 401(k) plans, ${ }^{87}$ but the qualification rules would be simplified. Under the SIT Plan, contributions to Save at Work accounts would be made on a pretax basis and withdrawals would be taxed as ordinary income; under the GIT Plan, contributions would be made on an after-tax basis and withdrawals would not be taxed. ${ }^{88}$

Both reform Plans would introduce AutoSave "default rules" that would provide for automatic enrollment, growth over time in contribu-
77. Id.
78. Id.
79. $I d$
80. Id.
81. Id. at 85 .
82. Id.
83. Id.
84. Id. at $115,159-60$.
85. Id at $114,159$.
86. Id. at 93,115 .
87. Id. at $117,159-60$.
88. Id. at $115-18,159-60$. 
tions, diversified investments, and automatic rollover should the employee change jobs. ${ }^{89}$ The employee would be given the opportunity to opt out. ${ }^{90}$ It is not clear from the Panel's report whether traditional profit-sharing, money purchase, or Keogh plans would also be replaced by save at work plans. ${ }^{91}$

The Save for Retirement accounts would replace all current IRAs as well as deferred executive compensation plans. ${ }^{92}$ Contributions of up to $\$ 10,000$ per year would be permitted into those accounts with no income phaseouts for contributions. ${ }^{93}$ Those accounts would be fully backloaded, in that contributions would be "after tax" with no tax on account earnings. Tax-free distributions would be permitted after age fifty-eight, or upon death or disability. ${ }^{94}$ Tax and penalties would apply to distributions for any other reason.95

Roth IRAs would be automatically converted to Save for Retirement accounts. ${ }^{96}$ Existing traditional IRAs (including those to which nondeductible contributions were made) could be converted into a Save for Retirement account by subjecting the value of those accounts to taxes once, similar to a current-law conversion of a traditional IRA account to a Roth IRA account. ${ }^{97}$ Income limits would not restrict conversions. ${ }^{98}$ Save at Work accounts could be rolled directly from an employer plan into a Save for Retirement account by paying income tax on the rollover amount. ${ }^{99}$ Existing traditional IRAs that could not be converted into Save for Retirement accounts would continue to exist, but the plans would require contributions to the Save for Retirement accounts. ${ }^{100}$

The Save for Family accounts would replace all other tax-favored savings vehicles in the tax code (health savings accounts, flexible spending accounts, education accounts, and so on). Individuals would be permitted to make contributions of up to $\$ 10,000$ each year in those accounts. ${ }^{101}$ There would be no income phaseouts and earnings would be tax-free. ${ }^{102}$ Withdrawals would be limited to $\$ 1,000$ each year for any purpose and unlimited withdrawals would be permitted to cover health costs, education expenses, home purchase, or retirement. ${ }^{103}$

The Panel recommended a refundable "savers credit," which would equal $25 \%$ for contributions up to $\$ 2,000$ that are made into those ac-

89. Id. at $118-19$.

90. Id. at 119.

91. Id. at $118-19$.

92. Id. at 119 .

93. Id.

94. Id. at 120 .

95. Id. at $119-20$.

96. Id. at 119 .

97. Id.

98. Id.

99. Id. at 119.

100. Id. at 119-20.

101. Id. at 120 .

102. Id.

103. Id. at 120-21. 
counts. ${ }^{104}$ The rules would be coordinated with the work credit to target that benefit to lower-income savers, and the credit would phase out ratably as income rises. ${ }^{105}$

The Panel also recommended as part of the SIT Plan a more consistent treatment of savings held outside of those tax-preferred accounts. ${ }^{106}$ Currently, there are no annual limits on the tax benefits for some deferred compensation arrangements and increases in the cash value of annuities and life insurance. The Panel recommended putting new rules in place to treat those arrangements like other investments. ${ }^{107}$

Regarding the inside buildup in some life insurance and annuity policies, the Panel recommended treating the increase in value in those policies as current income that would be subject to tax annually, at the taxpayer's ordinary income tax rate. ${ }^{108}$ However, the SIT Plan would allow whole-life insurance policies and deferred annuities to be purchased like other financial investments through tax-deferred Save for Retirement and Save for Family accounts, subject to the dollar limits. ${ }^{109}$

Also, the Panel Report provided that annuities, life insurance arrangements, and deferred compensation plans currently in existence would continue to be taxed under current-law rules. ${ }^{110}$ In general, the SIT Plan would tax interest income (other than that from tax-exempt municipal bonds) earned outside the tax-favored vehicles at ordinary income rates. ${ }^{111}$ The GIT Plan would tax interest income (other than that from tax-exempt municipal bonds) at a rate of fifteen percent. ${ }^{112}$ Both reform plans would maintain current-law treatment of state and local tax-exempt bonds for individual investors. ${ }^{113}$ Under the SIT Plan, however, the Panel recommended eliminating the exclusion from business income for state and local tax-exempt bond interest. ${ }^{114}$ "As under current law, individual investors would be able to deduct the amount of interest incurred to generate taxable investment income. The deduction for investment interest would be limited to the amount of taxable investment income reported by a taxpayer."115

In general, I believe these recommendations for individual tax reform make sense. They amount to significant simplification of current law and are likely to increase savings (especially through the AutoSave proposal). Thus, they should form part of any reform package that emerges from Congress.

104. Id. at 122 .

105. Id. at $122-23$.

106. Id. at 123 .

107. Id. at 123-24.

108. Id. at 123 .

109. Id.

110. Id. at 124.

111. Id.

112. Id. at 159 .

113. Id. at 126 .

114. Id.

115. Id. 


\section{THE REPORT PROPOSALS: TAXATION OF SAVINGS}

\section{A. Description of Proposals}

The taxation of income from savings differs significantly between the two Plans. The SIT Plan envisions full corporate integration for United States corporations. Foreign-based firms would not be eligible for that treatment. Under the plan, individuals and corporations would be able to exclude $100 \%$ of dividends attributable to domestic earnings. ${ }^{116}$ Corporations would notify shareholders of the portion of dividends subject to tax based on the proportion of the corporation's income not subject to United States taxation in the prior year. ${ }^{117}$

In addition, under the SIT Plan, individuals could exclude $75 \%$ of capital gains attributable to sales of corporate stock held for longer than one year, with the remaining $25 \%$ of capital gain includable in an individual's taxable income and taxed at ordinary rates. ${ }^{118}$ The Panel noted that the special treatment for corporate capital gains is warranted to level the playing field between businesses that pay out earnings in the form of dividends and those that retain earnings when shareholders realize those gains on disposition of the corporate stock. ${ }^{119}$ All other capital gains received by individuals would be taxed as ordinary income, as would interest income. ${ }^{120}$

Thus, under the SIT Plan dividends are generally taxed at $0 \%$, capital gains from the sale of stock (assuming an individual in the top bracket of $33 \%$ ) at $8.25 \%$, and other capital gains and interest income at $33 \% .121$

In the GIT Plan, on the other hand, all dividends (from foreign as well as domestic corporations), interest, and capital gains are taxed at a uniform rate of $15 \% .{ }^{122}$ In this sense the GIT Plan is more similar to current law which generally applies a $15 \%$ rate to dividends and capital gains. ${ }^{123}$

\section{B. Evaluation}

In my opinion, the GIT Plan is superior to the SIT Plan in the proposals for taxation of income from savings. To explain why, it is necessary to review the arguments for corporate integration. ${ }^{124}$ Historically, there have been three reasons advanced for countries to adopt corporate/shareholder integration to overcome biases in the classical system:

1. Under the classical system, there is a bias to conduct business in non-corporate forms, since they are not subject to double taxation

116. Id. at 124 .

117. Id. at $124-25$.

118. Id. at 125 .

119. Id. at 124 .

120. Id. at 125 .

121. Id.

122. Id. at 159 .

123. Id. at 157.

124. See Reuven S. Avi-Yonah, The Pitfalls of International Integration: A Comment on the Bush Proposal and Its Aftermath, 12 INT'L TAX \& PUB. Fin. 87 (2005). 
(although this is mitigated if the individual rate exceeds the corporate rate, since in corporate form the individual tax can be deferred); 2. Under the classical system, there is a bias to avoid dividend distributions and instead retain earnings, thus avoiding the double tax (this bias is exacerbated when the individual rate exceeds the corporate rate);

3. Under the classical system, there is a bias in favor of capitalizing corporations with debt (producing deductible interest) rather than equity (producing non-deductible dividends). ${ }^{125}$

None of these arguments are completely convincing, which may be a reason why the United States maintained the classical system from 1936 to 2003, and indeed strengthened it in 1986 with the repeal of the "General Utilities" doctrine, which enabled corporations to avoid corporate $\operatorname{tax}$ on a distribution of appreciated assets. ${ }^{126}$ First, the alleged bias against the corporate form is mitigated to the extent the top individual rate exceeds the corporate rate, as it generally did until 2003 , and by the absence of strong provisions to prevent retentions in the domestic context (the accumulated earnings tax and the personal holding company tax are both weak.)

In addition, under current rules, the classical system applies primarily to large, publicly traded corporations, while small, closely-held businesses are able to avoid the double tax even if they are in corporate form for non-tax purposes. It is doubtful, if there is sufficient substitutability between the two forms of business, for the double tax to create much deadweight loss ("DWL") from the bias toward non-corporate form. Most estimates of the DWL from this bias are quite low. For example, Professor Austan Goolsbee found that an increase in the corporate tax rate by $10 \%$ reduces the corporate share of firms by $5 \%-10 \%$ and the corporate share of sales and employment by $2 \%-6 \% .{ }^{127}$ Goolsbee concluded that "[the] impact of tax rates is and order of magnitude larger than previous estimates ... and suggests a larger DWL from corporate taxation, but is still relatively modest." 128 The double tax is a price large businesses have to pay for access to the public equity markets and the liquidity that accompanies such access. From this perspective, the corporate tax is essentially a benefit tax on large organizations that want to take advantage of the corporate form. Given that most large firms in the United States are

125. Michael J. Graetz \& Alvin C. Warren Jr., Integration of the United States Corporate and Individual Income Taxes: The Treasury Department and American Law Institute Reports (1998).

126. For other reasons see Jennifer Arlen \& Deborah M. Weiss, A Political Theory of Corporate Taxation, 105 Y ALE L.J. 325 (1995); Steven A. Bank, Corporate Managers, Agency Costs and the Rise of Double Taxation, 44 WM. \& MARY L. REV. 167-216 (2003). For an explanation of the "General Utilities" doctrine, see Bernard Wolfam \& Diane M. Ring, Federal Income Taxation of Corporate Enterprise 25 (4th ed. 2005).

127. Austan Goolsbee, The Impact and Inefficiency of the Corporate Income Tax: Evidence from State Organizational Form Data (Nat'l Bureau of Env'l Research, Working Paper No. 9141, 2002), available at http://nber.org/papers/w9141.

128. Id. at 15 . 
incorporated, it follows that the benefits of incorporation must outweigh the (tax) costs.

Finally, to the extent that the corporate tax can be shifted to consumers or to labor, the bias disappears, and the Treasury's 1991 integration study and many others have suggested that considerable shifting can take place. ${ }^{129}$ The bias reappears again if non-corporate businesses can likewise shift the individual tax burden, but it seems plausible that the shifting potential of large multinationals is larger than that of small, closelyheld businesses. ${ }^{130}$

Second, the bias in favor of retentions is reduced when (as both before and after 2003) the corporate rate is not significantly lower than the individual rate. In addition, this bias was mitigated before 2003 by the ability of corporations to redeem shares from shareholders at the favorable capital gains rate, and by the fact that numerous shareholders are tax-exempt or corporate (and thus do not pay a full tax on dividends). Even when the tax rate on dividends is the same as that on capital gains (as under the GIT Plan), capital gain transactions may still be preferred for the ability to offset basis. That is why many United States corporations have adopted structured redemption programs addressed to their taxable individual shareholders. Other corporations retain all their earnings, but it is not clear that this is primarily tax-motivated (corporations used to pay dividends under the same rules in the past). Admittedly, more corporations are paying dividends now than in previous years, but this trend began before 2003, and again it is not clear that this is primarily taxmotivated. Finally, there is an unresolved debate among economists as to whether the dividend tax is capitalized into the price of the shares. ${ }^{131}$ If it is, then the retention bias applies only to new equity, but new equity is unlikely to pay dividends for non-tax reasons.

Third, the bias in favor of debt and against equity is a general problem of the income tax that should not be addressed only in the corporate tax

129. See also Martin Feldstein, Incidence of a Capital Income Tax in a Growing Economy with Variable Savings Rates, 41 REv. ECON. STuDs. 505 (1974); Don Fullerton \& Gilbert E. Metcalf, Tax Incidence, in HANDBOOK of Public Economics (Alan J. Auerbach \& Martin Feldstein eds., 2002); GraEtz \& WARREN, supra note 125; Ronald E. Grieson, The Incidence of Profits Taxes in a Neo-Classical Growth Model, 4 J. PuB. ECON. 75 (1975); Arnold C. Harberger, The Incidence of the Corporation Income Tax, 70 J. PoL. Econ. 215 (1962); Masaaki Homma, A Dynamic Analysis of the Differential Incidence of Capital and Labour Taxes in a Two-Class Economy, 15 J. PuB. ECON. 363 (1981); Kenneth L. Judd, Redistributive Taxation in a Simple Perfect Foresight Model, 28 J. Pub. ECON. 59 (1985); Casey B. Mulligan, Capital Tax Incidence: First Impressions from the Time Series (Nat'1 Bureau of Econ. Research, Working Paper No. 9374, 2002), available at http://nber.org/ papers/w9374.

130. See generally Fullerton \& Metcalf, supra note 129; John Mutti \& Harry Grubert, The Taxation of Capital Income in an Open Economy: The Importance of Resident-Nonresident Tax Treatment, 27 J. PuB. EcoN. 291 (1989).

131. See, e.g., Robin Boadway \& Neil Bruce, Problems with Integrating Corporate and Personal Income Taxes in an Open Economy, 48 J. PuB. ECON. 39 (1992); David Bradford, The Incidence and Allocation Effects of a Tax on Corporate Distributions, 15 J. PuB. Econ. 1 (1981). 
area. ${ }^{132}$ Moreover, to address it completely, it is necessary to make dividends deductible rather than exempt, a form of integration that has never been adopted (in part because it would automatically extend integration to foreign and tax-exempt shareholders). If integration takes the normal forms of imputation or dividend exemption, there is still a difference in treatment between interest and dividends that can be manipulated. For example, if interest is taxed but dividends are not, there can be clientele effects (tax exempt entities will hold bonds and taxable shareholders stock, as well as invest in stock and use derivatives to turn this economically into an investment in bonds). ${ }^{133}$ Neither of these problems arise if both interest and dividends are deductible or (as under the Treasury's 1991 CBIT model) non-deductible, but neither of these applies under the SIT Plan, ${ }^{134}$

From these perspectives, the GIT Plan is superior to the SIT Plan precisely because it has the same rate for dividends, interest, and capital gains. In the SIT Plan, the gain from integration (fully exempting dividends) may be more than offset by the transaction costs of planning around the different treatment of dividends, interest, and capital gains.

In addition, the GIT Plan treatment of dividends is superior to the SIT Plan treatment because it (like current law) does not discriminate between dividends from domestic and foreign corporations. Even if one accepts the validity of all the biases generated by the classical system set out above, all of them need to be offset by the countervailing biases created by integration in the international context. From a theoretical perspective, two situations need to be considered: when the source country is integrationist and the residence country classical, and when the source country is classical and the residence country integrationist. In the following, I will first lay out the theoretical problem, and then apply it to the SIT and GIT Plans.

Classical residence country: If a portfolio investor residing in a classical country invests in shares of a company of an integrationist country, the resulting bias depends on the form taken by integration. If the source country grants integration in the form of dividend exemption, the classical country investor would not benefit since the classical country would tax him on the dividend without allowing a foreign tax credit for underlying corporate taxes. A domestic investor in the source country would be subject only to the corporate tax, while the classical country investor would be subject to the corporate tax, any foreign withholding tax on dividends, and the residual classical country tax.

If the source country grants integration by way of imputation credits, the key issue is whether such credits are extended to foreign investors (by

132. See generally Alvin C. Warren Jr., Financial Contract Innovation and Income Tax Policy, 107 HARV. L. Rev. 460 (1993); Bradford, supra note 131; Joseph E. Stiglitz, Taxation, Corporate Financial Policy, and the Cost of Capital, 2 J. PUb. ECON. 1 (1973).

133. Warren, supra note 132.

134. GRAETZ \& WARREN, supra note 125 . 
treaty or otherwise). If (as is typical) the credits are not extended to foreigners, a domestic investor would only be subject to tax at his or her individual rate, while the classical country investor would be subject to $\operatorname{tax}$ at the corporate level, any withholding tax on dividends, and the residual classical country tax. Whether the combination of these taxes exceeds the source-country tax on domestic investors depends on how high the source-country rates are (it is conceivable, for example, that a combined tax on the classical country investor of sixty percent would be matched by the single level source country tax on a domestic investor).

If the imputation credits are extended to classical country investors, a different bias arises. In that case, both domestic source country and classical country investors in a foreign corporation would be taxed the same by the source country, but the cost of imputation credits to classical country investors would be borne by the source country, while any tax on the dividend would be collected by the classical country. From a classical country perspective, moreover, there would be a bias in favor of investing in source country corporations and against investing in classical country corporations, since only dividends from the former would carry the imputation credits. Such a bias would not be eliminated by the classical country taxing the dividends in full, since the investor would still receive an imputation credit check from the source country not available for her classical country investment.

Classical source country: If the integrationist residence country grants integration by way of dividend exemption, presumably the exemption would apply to dividends from the classical country as well as from domestic corporations (this is true for many dividend exemption countries but not for others, and is generally true under the GIT Plan but not under the SIT Plan). In that case, a bias is created in favor of foreign investors in classical country companies, since they would be exempt from tax on the dividend (unless a classical country withholding tax applies, but such taxes are generally reduced by treaty or avoided by other devices). By contrast, a classical country domestic investor would be taxed on the dividends in full.

If the foreign country grants integration by way of imputation credits, there will be no credits available for a foreign investor who invests directly in a classical country company. In that case, there will be a bias in favor of the foreigner investing in her own country's domestic corporations. This bias may be partially eliminated if credit is given for classical country taxes to a domestic portfolio investor in a domestic company with classical country source income. But, similar to the case of a dividend exemption, that would create a bias in favor of foreign investors in such companies over classical country investors in a domestic classical country corporation.

Thus, from a theoretical perspective, as long as there are both classical and integrationist countries in the world, integration creates biases that 
do not arise in a world with only classical countries. ${ }^{135}$ Theoretically, the biases could also be eliminated in a world in which all countries practiced integration and extended its benefits to foreign investors and investments, but this seems a very unrealistic scenario, which is certainly not fulfilled under present conditions.

Under the SIT Plan, dividend exemption only applies to dividends from domestic corporations, which are exempt if the corporation's income was fully taxed. This is true even if the dividend derived from United States corporations with foreign source income (through a branch or subsidiary), since both direct foreign taxes and withholding taxes can be counted as equivalent to United States taxes. Dividends from foreign corporations, on the other hand, are fully taxed, with a credit available only for foreign withholding taxes and for United States taxes on effectively connected income. Significantly, United States portfolio investors investing in foreign corporations with United States source income do not get a credit even for United States withholding taxes or branch profit taxes. The SIT Plan thus creates a very significant bias against investing in foreign corporations. In the context of an open economy, this bias could well lead to greater welfare losses to United States portfolio investors than their gains from domestic integration.

The GIT Plan does better in this regard since it applies the lower $15 \%$ rate to dividends from foreign corporations, as well as from domestic corporations. ${ }^{136}$ Nevertheless, the GIT Plan creates another bias in terms of the sourcing of equity capital to United States corporations, since they would have an incentive to raise such capital domestically $(15 \% \operatorname{tax}$ on dividends) rather than from foreign investors in classical countries or integrationist countries that do not extend dividend exemption to foreign investments (United States withholding tax at $15 \%$ plus residual residence country tax). In addition, corporations in classical countries may be biased in favor of raising capital from United States investors rather than from domestic investors.

From a theoretical perspective, there seems to be no reason to assume that the biases created by integration from an international perspective are less important than the biases created by the classical system from a domestic perspective. In fact, the former may be gaining in importance as cross-border investment grows, while (as discussed above) there are reasons to doubt the importance of the latter. This is the reason why many countries (for example, Germany and the U.K.) have recently been re-

135. See generally Peter A. Harris, Corporate/Shareholder Income Taxation (1996); Hugh J. Ault, Corporate Integration, Tax Treaties and the Division of the International Tax Base: Principles and Practices, 47 TAX L. Rev. 565 (1992); Reuven S. AviYonah, The Structure of International Taxation: A Proposal for Simplification, 74 Tex. L. Rev. 1301 (1996); Howell H. Zee, Taxing Caputal in a Globalized World, 27 TAX Notes INT'L 1185 (2002).

136. REPORT, supra note 1 , at 159 . 
stricting integration. ${ }^{137}$ If the whole world reverted to the classical system, the international biases would be eliminated.

Nevertheless, in the foreseeable future, some countries will continue to grant integration, while others are likely to maintain a classical system. In that situation, it is necessary to make a choice between the international biases described above, which is similar to the choice between capital import neutrality ("CIN") (treating all investors in the source country alike) and capital export neutrality ("CEN") (treating all investment opportunities to a resident investor alike). Since most of the empirical evidence continues to suggest that the elasticity of the demand for capital is greater than the elasticity of the supply of capital, it is likely that most economists would support a continued preference for CEN (neutrality in the allocation of investments) over CIN (neutrality in the allocation of savings).

If one prefers $\mathrm{CEN}$, this suggests that integrationist source countries should not extend integration benefits to foreign investors (since that would violate CEN while maintaining CIN). This is consistent with current practice. When the integrationist country is the residence country, integration benefits should be extended to investments in classical source countries. This can be done by granting integration credits for taxes paid to the source country, either through a domestic corporation (which is common) or even through a foreign corporation (less common but possible- it is equivalent to granting the indirect foreign tax credit to portfolio United States investors, which would raise many difficult administrative issues). A simpler solution, however, is to partially or fully exempt dividends from both domestic and foreign corporations, as is achieved under the GIT Plan (but emphatically not under the SIT Plan). This would still leave a bias in the form of a dividend withholding tax imposed by the source country (plus a branch profits tax if the investment is through a foreign corporation), but in the case of the United States, portfolio investors can usually avoid the dividend-withholding tax.

Thus, the GIT Plan method of integration (partially exempting dividends from both domestic and foreign corporations) is superior from an international perspective to the SIT Plan. The GIT Plan result preserves CEN as far as the United States is concerned, but there is still a bias in favor of investing in domestic corporations to the extent foreign source countries levy a withholding tax on dividends. In addition, foreign investors in United States corporations are still disadvantaged compared to United States investors, either because of United States withholding taxes on dividends (which the United States can and should abolish) or because their country of residence taxes dividends (which the United States can do nothing about).

Overall, though, it seems to me that the argument for corporate integration is shaky. Thus, I would prefer, even under the GIT Plan, to have dividends, interest, and capital gains taxed as ordinary income (at thirty-

137. See generally Richard J. Vann, General Report, 88a CAHIERS DE DROIT FISCAL INTERNATIONAL 21 (2003). 
three percent) like they were (briefly) under the 1986 Tax Reform Act. ${ }^{138}$ Despite the current push toward "dual tax systems," I do not think there is anything in the international or domestic environment that forces the United States to adopt a lower rate for income from savings. I am not aware of any empirical evidence for capital flight from the United States in response to a $33 \%$ tax rate on income from savings, and I would generally support such a tax for the reasons set out above.

\section{THE REPORT PROPOSALS: BUSINESS TAXATION}

\section{A. Description of Proposals}

The SIT Plan calls for using a clean tax base for the corporate tax and eliminating all credits and special preferences, except for accelerated depreciation. The Panel report specifically highlighted the elimination of the $\S 41$ research credit, the recently enacted $\S 199$ production deduction, and the corporate deduction for state and local income taxes. ${ }^{139}$

The corporate tax rate would be reduced to $31.5 \%$ and would be paid by all business entities regardless of form (that is, passthrough entities like partnerships, S corporations, and limited liability companies would pay the corporate tax rate at the entity level). ${ }^{140}$ Large businesses would be defined as having annual receipts of $\$ 10$ million or more. ${ }^{141}$ Passive investment vehicles like regulated investment companies and real estate investment trusts would be treated as under current law. In addition, the plan would abolish the corporate AMT. ${ }^{142}$

The Panel noted that it evaluated a proposal to tax large business entities based on financial statement net income, as opposed to requiring a separate calculation of taxable income as under current law, and it recommended further study of that concept. ${ }^{143}$

The Panel also recommended a greatly simplified cost-recovery system for large taxpayers-replacing the nine different asset class lives, three different recovery methods, and three different applicable conventions with a system using only four asset categories. ${ }^{144}$ The Panel envisioned the new system providing roughly the same cost-recovery deductions as does current law, but with simplification gains. ${ }^{145}$ Under the new plan, taxpayers would increase the balance in one of four property accounts by the amount of new purchases and be allowed a uniform allowance each year. ${ }^{146}$ Depreciation would be computed by multiplying the account's average balance by the depreciation rate applicable to the specific asset

138. Tax Reform Act of 1986, Pub. L. No. 99-514, 100 Stat. 2085.

139. REPORT, supra note 1 , at 129-32.

140. Id. at 129.

141. Id.

142. Id. at 108-09, 129-30.

143. Id. at 131.

144. Id. at 132 .

145. Id.

146. Id. 
class. ${ }^{147}$

The SIT Plan would simplify the rules governing small and mediumsize businesses and improve compliance in that area. Under the plan, small and medium-size businesses (firms with less than $\$ 10$ million in annual receipts) would be taxed on a cash basis at the top individual rate of thirty-three percent. ${ }^{148}$

Small businesses (with receipts less than $\$ 1$ million) would report income based on cash receipts less cash business expenses. ${ }^{149}$ This method would apply to all items of income and expense except for building and land purchases. ${ }^{150}$ Small businesses also would be permitted to immediately expense all business expenditures (except for building and land purchases, which would generally be treated as under current law). ${ }^{151}$ Thus, there would be no need for businesses to keep track of depreciation schedules for specific assets. Medium-size firms (with annual receipts between $\$ 1$ million and $\$ 10$ million) would be subjected to a simplified depreciation system for purchased business assets and, in some cases, a simplified inventory method for physical inventories. ${ }^{152}$ The gross receipts figure (for determining small and medium-size business eligibility) would be based on the firm's prior three-year average. ${ }^{153}$

Businesses with gross receipts less than $\$ 10$ million could elect to be treated as a large business to avail themselves of the exclusion rules for dividends and corporate capital gains. ${ }^{154}$

To aid with compliance, small and medium-size businesses would be required to set up a business bank account; those accounts could not be used for personal transactions. ${ }^{155}$ Banks would be required to provide to the IRS and to the taxpayer annual information reports on the transactions in and out of the accounts. ${ }^{156}$ Similarly, for those businesses, credit and debit card companies would be required to provide annual information reports summarizing business credit transactions. ${ }^{157}$

The SIT Plan would impose new disclosure requirements on foreign earnings and would adopt two international tax proposals that also had been developed by the staff of the Joint Committee on Taxation and included in a 2005 report entitled "Options to Improve Tax Compliance and Reform Tax Expenditures" ("JCT Report"). 158 In addition to the new disclosure requirements for foreign earnings, the Plan would replace

147. Id. at 131-32.

148. Id. at $127-28$.

149. Id. at 127 .

150. Id.

151. Id.

152. Id. at 128 .

153. Id.

154. Id. at 129.

155. Id. at 128 .

156. Id.

157. Id.

158. Id. at 134, 239; see generally StafF of THE J. CoMm. on TAXATION, 109TH Cong., Options to Improve Tax Compliance and Reform Tax Expenditures, JCS-02-05 (2005). 
the worldwide, deferral-based system of current law with a territorial tax regime and would define a publicly traded foreign-incorporated entity's residence by reference to the location of its primary place of management and control. ${ }^{159}$

The Plan would contemplate new reporting requirements for United States multinational corporations, including the filing of a new schedule with their income tax return that shows consolidated worldwide revenues and income before taxes, as reported in their annual financial statements. ${ }^{160}$ The new schedule would disclose the proportion of domestic and foreign revenues and income. ${ }^{161}$ Also, businesses would be required to reconcile the income reported on their books with the taxable income reported on their returns. ${ }^{162}$

The SIT Plan would retain some features of current law, like subpart F. Branches and controlled foreign corporations (foreign affiliates) would be placed on an equal footing, with income of foreign branches treated like income of a foreign affiliate. ${ }^{163}$ Under a general rule, payments that are deductible abroad would be taxed in the United States. ${ }^{164}$ A foreign tax credit would be available to offset tax on passive and highly mobile income, subject to a single, overall FTC limitation. ${ }^{165}$

The Panel's recommendation would also modify the definition of businesses that are subject to United States tax by providing a "comprehensive rule" that treats a business as a resident of the United States if the United States is either the place of legal residency or the business's place of "primary management and control."166

Under the GIT Plan, all businesses (except sole proprietorships) would be taxed at a thirty percent rate on their cash flow (defined as total sales less purchase of goods and services from other businesses and less wages and other compensation paid to employees). ${ }^{167}$ Sole proprietorships would be taxed at ordinary individual income rates. ${ }^{168}$ Flow-through entities, like partnerships and LLCs, would also be taxed at the thirty percent rate on their business cash flow, although owners of those entities could report and compute the tax on their individual returns. ${ }^{169}$

Companies would be able to immediately expense all business investments, including all employee wages and other compensation. ${ }^{170}$ That plan also would remedy the current code's preference for debt financing over equity financing. Nonfinancial businesses would not be taxed on in-

159. REPORT, supra note 1 , at 134-35, 239-41.

160. Id. at 244 .

161. Id.

162. Id. at 244 .

163. Id. at 134 .

164. Id.

165. Id. at $240-41$.

166. Id. at 135 .

167. Id. at 162 .

168. Id.

169. Id.

170. Id. at 164 . 
come from financial transactions like dividend and interest payments, but they would not receive any deductions for interest paid or other financial outflows. ${ }^{171}$ Firms that generate losses could carry those losses forward indefinitely, and those carryforwards would accrue interest. ${ }^{172}$

Under the GIT plan, financial institutions would be treated very differently from nonfinancial institutions, necessitating new definitions and a significant change in the tax base. Financial institutions would treat all principal and interest inflows as taxable income and deduct all principal and interest outflows. ${ }^{173}$ Customers of financial institutions would disregard financial transactions for tax purposes. ${ }^{174}$ Complicated rules would prevent the "over-taxation of business purchases of financial services" attributable to deductible financial intermediation services (which would be deductible as an expense for the customer). ${ }^{175}$

Rules would be necessary to determine which businesses qualify as financial institutions, particularly in the case of businesses with both financial and nonfinancial business activities. The report recognized that there may be an incentive for nonfinancial services firms to characterize transactions as financial to escape taxation (for example, the Appendix to the Panel's report contains an example of a car dealership posting a low sales price on a car but selling the car on credit with a high financing charge). ${ }^{176}$ A similar incentive may exist to recharacterize nonfinancial transactions as financial in the case of derivatives (for example, the Panel's report indicated that a derivative entered into to hedge a nonfinancial business asset or liability should be taxed in a manner similar to the treatment of the underlying asset-subject to the cash flow tax). ${ }^{177}$

Also, an interest rate that would be used as a proxy for the financial cost component of financial cash flows would have to be established to determine the value of the separate taxable service component. ${ }^{178}$

The GIT Plan would tax international transactions under a "destination basis" principle, with border tax adjustments (that is, imports would not be deducted from cash flow and the cash flow tax would be rebated on exports). ${ }^{179}$ The Panel, however, did not provide definitive recommendations regarding important implementation issues. In particular, the Report indicates that it is unclear whether the GIT Plan can be compatible with the rules of the WTO for border adjustability, and its revenue estimates do not assume border adjustability. ${ }^{180}$

171. Id.

172. Id. at 167.

173. Id. at 166 .

174. Id.

175. Id. at $166,245$.

176. Id. at 245 .

177. Id.

178. Id. at 166.

179. See id. at 167-72.

180. Id. at 171-72. 


\section{B. Evaluation}

In general, both the SIT and GIT Plans achieve significant improvement and simplification over the current corporate tax.

The major advantage of the SIT Plan is to eliminate the distinction between Subchapter C corporations and other forms of large business. This is similar to business taxation in other countries and represents a step forward, eliminating one argument for corporate integration (the bias against the corporate form). The cleaned-up corporate tax base and simplified taxation of small businesses are likewise steps in the right directions.

I fully approve the Report's endorsement of the Joint Committee proposal for a managed and controlled residency definition, which will deal a blow to inversions (and close the loopholes and overcome the grandfathering provisions in current law). ${ }^{181}$

I have more concerns about the territoriality proposal. While not as bad as some proposals for territoriality in retaining Subpart F and generally taxing passive income, territoriality in taxing active income suffers from three flaws: first, it puts great pressure on the source rules; second, it encourages transfer pricing; and third, it encourages harmful tax competition. ${ }^{182}$

The increased need to police the source rules and transfer pricing means that the simplification advantages from territoriality are likely to be lost because of the increased transactional complexity. Moreover, the retention of both the foreign tax credit and Subpart F mean that the proposal does not achieve much simplification to begin with. ${ }^{183}$

The main argument for territoriality is competitiveness, but as I have written elsewhere, our trading partners are not fully territorial either, and competitiveness can better be addressed by multilateral action through the Organization for Economic Corporation and Development ("OECD"). ${ }^{184}$ Adopting the Report proposal will surely lead to expansion of territoriality by our trading partners and increased tax competition.

The GIT Plan is a subtraction type VAT. However, there are three strange aspects of this VAT. First, the treatment of financial institutions is different than in most countries that have a VAT, and seems unnecessarily complex. There is no reason to reinvent the wheel in this regard: As South Africa has shown, it is possible to implement a VAT that disregards

181. This proposal was first developed in Reuven S. Avi-Yonah, For Haven's Sake: Reflections on Inversion Transactions, 95 TAX NOTES 1793 (2002).

182. See generally Reuven S. Avi-Yonah, Comment on Peroni, Fleming \& Shay, "Getting Serious About Curtailing Deferral of United States Tax on Foreign Source Income," 52 SMU L. REV. 531 (1999).

183. See Lee A. Sheppard, News Analysis: A Look at the United States Tax Reform Plan's International Provisions, 40 TAX Notes INT'L 675 (2005).

184. Reuven S. Avi-Yonah, Tax Competition and Multinational Competitiveness: The New Balance of Subpart F-Review of the NFTC Foreign Income Profject, 18 Tax NoTES INT'L 1575 (1999). 
interest income and expense even for financial institutions and still taxes financial intermediation services. ${ }^{185}$

Second, it seems strange to combine a VAT with an income tax on savings. In my opinion we are better off retaining the income tax (as in the SIT Plan) and, in addition, adopting a VAT, as in the GIT Plan. The GIT Plan as it stands is a strange hybrid of income tax treatment for individuals and consumption tax treatment for businesses.

Finally, because of the attempt to make the business part of the GIT Plan look like an income tax by giving a deduction for wages, combined with a tax on income from savings, it seems clear that the GIT Plan would not qualify as border adjustable under the GATT, which allows border adjustability for the VAT but not for direct taxes. ${ }^{186}$ If the GIT Plan is not border adjustable, it must allow a deduction for imports and include exports. Since we import more than we export, the short-term revenue impact of losing border adjustability due to the GIT Plan is very considerable. In addition, allowing a deduction for imports raises significant transfer pricing concerns that do not arise under a border adjustable system.

\section{A PROPOSAL FOR REFORM: COMBINING SIT AND GIT}

A major constraint imposed on the Panel by the President was that its proposal had to be revenue neutral. The Panel claims to have met this goal, although outside observers dispute this claim and argue that both proposals would lose revenue. ${ }^{187}$

However, my main problem with the Report from this perspective is that we cannot afford revenue neutrality under present circumstances. To finance the retirement and health needs of the baby boom generation, not to mention urgent needs like extending health insurance to all Americans, we face a budgetary gap of $\$ 70$ trillion dollars. There is simply no way to raise this kind of revenue with the existing income tax. Raising income tax rates to the levels of the 1970s or earlier is counter-productive because it imposes too high of a burden on the decision to work, and because it drives away investors in the face of global tax competition. Thus, if we do not want to unravel the social compact of the New Deal by drastically cutting benefits, we need to adopt a VAT in addition to the existing income tax.

I would propose that we adopt portions of both the SIT and GIT Plans. ${ }^{188}$ The individual part of the Plans is identical except for the rate

185. See generally Avi-Yonah, supra note 3.

186. See generally Reuven S. Avi-Yonah, The WTO, Export Subsidies, and Tax Competition, in WTO \& Direct TAXATION 115 (Michael Lang, Judith Herdin, \& Ines Hofbauer eds., 2005) (discussing the GATT rules).

187. See Leonard E. Burman \& William G. Gale, A Preliminary Evaluation of the Tax Reform Panel's Report, 109 TAX Notes 1349 (2005); Daniel Shaviro, A Blueprint for Future Tax Reform? Evaluating Reform Panel's Report 109 TAx Notes 827 (2005).

188. This proposal is similar to the proposal advanced in more detail in Avi-Yonah, supra note 3. See also Avi-Yonah, supra note 40. 
structure, so it can be adopted as is (the determination of rates depends on revenue estimates, so I have no view on the rate structure). The GIT Plan proposal for taxing income from savings is in my view superior and should be adopted, except that the rate should be the same as the top ordinary income rate.

As for taxation of businesses, I would adopt simultaneously both the SIT Plan (except for the territoriality feature) and the GIT Plan (except that I would eliminate the deduction for wages in the GIT Plan and possibly modify the taxation of financial institutions as well). In that case the business portion of the GIT Plan would simply be a VAT adopted in addition to an income tax, and it will clearly be border adjustable.

\section{CONCLUSION}

By adopting both the SIT Plan and the business tax part of the GIT Plan, we will join most other countries in the world (and every other member of the OECD) in having both a much improved and simplified income tax and a VAT. ${ }^{189}$

The adoption of a VAT on top of the income tax is likely to be opposed by both conservatives and liberals. Conservatives will argue that increasing the overall share of the government in GDP from about $30 \%$ to about $40 \%$ (the average level in the OECD) will slow economic growth. They may be right, but the level of economic growth in other OECD member countries has been acceptable, and in some cases (for example, Europe) has been hindered by other factors we do not face, like low labor mobility. I believe that a slightly lower growth rate is an acceptable price to pay for ensuring a decent retirement and health-care package for the baby boom generation.

Liberals are likely to oppose the VAT because it is regressive. That is true, but as I have explained elsewhere, the regressivity of the VAT can be offset by using the revenues in progressive ways. ${ }^{190}$ Both social security and Medicare are progressive, and if needed, some of the revenue can be rebated to lower-income families to ensure further progressivity.

In 2003, the United States joined most of the OECD in enacting a form of corporate-shareholder income tax integration. While I have misgivings about this reform, it was a step towards eliminating one of the basic ways in which our tax structure differed from that of other OECD member countries. The time has come to eliminate the other, more glaring abnormality of our tax system by adopting a VAT in addition to the existing income tax. The political prospects for this type of radical tax reform may be dim at present; but every year that brings the baby boomers closer to retirement will make those prospects brighter.

189. This was in fact the recommendation of the OECD. See OECD, ECONOMIC SurVEY OF THE UNITED STATES (2005), available at http://www.oecd.org/dathoecd/4/11/ 35541272.pdf.

190. See Avi-Yonah, supra note 40. 